\title{
Albumin Administration in Exchange Transfusion for Hyperbilirubinaemia
}

\author{
ANN COMLEY and BEN WOOD \\ From the Birmingham Maternity Hospital, Loveday Street, Birmingham
}

Exchange transfusion for neonatal hyperbilirubinaemia is usually carried out using twice the infant's blood volume of donor blood over a period of about 100 minutes (Forfar et al., 1958; Valaes, 1959). The importance of the albumin fraction in the plasma has been emphasized by $\operatorname{Odell}(1959 \mathrm{a}, \mathrm{b})$, who showed that the diffusion of bilirubin between plasma and the extravascular tissues is influenced by the capacity of albumin to bind the pigment. During an exchange transfusion the albumin in the donor blood replaces the infant's bilirubin-laden protein, and thus promotes movement of bilirubin from extravascular tissues into the circulation.

Kitchen, Krieger, and Smith (1960) claimed that by substituting $12.5 \mathrm{~g}$. salt-poor human albumin in $50 \mathrm{ml}$. water for an equal volume of whole blood at the beginning and again half-way through an exchange transfusion the efficiency of bilirubin removal was increased by about $50 \%$. Odell, Cohen, and Gordes (1962) 'primed' the infant with an intravenous injection of human albumin given 1 to 4 hours before exchange and in a dose of $1 \mathrm{~g}$. $/ \mathrm{kg}$. They obtained an apparent increase of $41 \%$ in bilirubin removal. Using one dose of $12.5 \mathrm{~g}$. salt-poor albumin in $50 \mathrm{ml}$. water in place of donor plasma, Waters and Porter (1964) obtained an increase in efficiency of $26 \%$.

The object of the present investigation was to evaluate the effect of human albumin administered either by substitution or by priming on bilirubin removal, albumin concentration, and bilirubin shift in the plasma of infants undergoing exchange transfusion.

\section{Material and Methods}

Infants requiring exchange transfusions for hyperbilirubinaemia were treated by three different methods. All those over 10 hours old (at which time plasma shift would be complete (Gairdner et al., 1958)) and whose pre-exchange bilirubin was over $12 \mathrm{mg}$. $/ 100 \mathrm{ml}$. were included. Infants were allotted to one of three groups

Received July 3, 1967. by random selection, and their composition as regards age, maturity, birthweight, haematocrit, and preexchange bilirubin level is shown in Table I.

Group $I$ (controls): 19 infants who were treated by simple exchange transfusion.

Group II (substitution exchanges): 17 infants who at every $100-\mathrm{ml}$. interval during the exchange had $10 \mathrm{ml}$. $(2.5 \mathrm{~g}$.) salt-poor human albumin substituted for the blood, similar to the method of Kitchen, and using a total of about $20 \mathrm{~g}$. albumin.

Group III (primed exchanges): 17 infants whose exchange transfusion was preceded by the intravenous injection of $2 \cdot 5-10 \mathrm{~g}$. albumin (approximately $1 \cdot 75 \mathrm{~g}$./ $\mathrm{kg}$.) 1-6 hours before the procedure. This was a larger dose of albumin than Odell's $1 \mathrm{~g}$. $/ \mathrm{kg}$.

Infants in all three groups were given two-volume exchange transfusions using the umbilical vein. Samples were taken into heparinized containers before and after exchange. Acid-citrate-dextrose blood with a haematocrit of approximately $50 \%$ was exchanged in $10 \mathrm{ml}$. aliquots over 60-146 minutes. All blood removed from the infant was collected in a dark-glass container with 2500 units heparin added. Care was taken to prevent contamination of waste blood by either saline washings, donor blood, or albumin. After measuring the volume removed, samples were taken for the various investigations. Haematocrit, bilirubin, and albumin concentrations were estimated within a few hours of collection when this occurred during laboratory working hours; otherwise haematocrit estimations were done by the authors, and plasma from centrifuged specimens was stored in the dark at $4^{\circ} \mathrm{C}$.

Plasma bilirubin was estimated spectrophotometrically (White, Haidar, and Reinhold, 1958) and plasma albumin concentration by a modification of the method described by Bartholomew and Delaney (1966).

Calculations of blood volume, plasma volume, total mass of intravascular bilirubin, and total mass of bilirubin removed were based on the work of Valaes (1963).

(1) Blood volume (BV). Mollison, Veall, and Cutbush (1950) found the mean blood volume in newborn infants to be $85 \mathrm{ml} . / \mathrm{kg}$., but that it differed according to age, early or late clamping of the cord, maturity, and venous haematocrit. By matching the three groups these factors should largely cancel out; blood volume was therefore calculated in $\mathrm{ml}$. as: birthweight in $\mathrm{kg} . \times 85$. 
TABLE I

Comparative Data of Infants in Groups I, II, and III

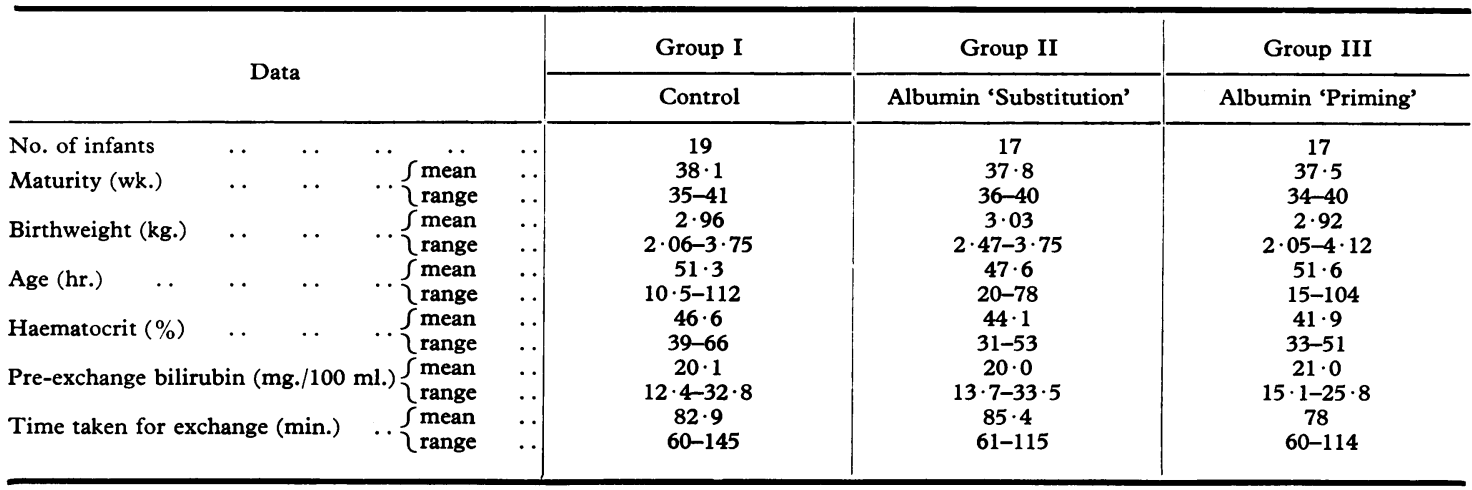

TABLE II

Bilirubin Removal in the Three Groups

\begin{tabular}{|c|c|c|c|c|}
\hline Data & Group I & Group II & Group III & $\begin{array}{c}\text { ^Significance of } \\
\text { Difference Between } \\
\text { Groups I and II }\end{array}$ \\
\hline $\begin{array}{ll}\text { Total mass of bilirubin removed (mg.) } & \left\{\begin{array}{l}\text { mean } \\
\text { range }\end{array}\right. \\
\text { Bilirubin removed (mg./kg.) } & \left\{\begin{array}{l}\text { mean } \\
\text { range }\end{array}\right. \\
\text { Bilirubin clearance per } 2 \text { volume plasma exchange } & \left\{\begin{array}{l}\text { mean } \\
\text { range }\end{array}\right.\end{array}$ & $\begin{array}{l}35 \\
14-76 \\
11 \cdot 9 \\
5 \cdot 4-20 \cdot 3 \\
123 \\
67-156\end{array}$ & $\begin{array}{l}46 \\
31-75 \\
15 \cdot 4 \\
9 \cdot 5-24 \cdot 4 \\
142 \\
108-170\end{array}$ & $\begin{array}{c}41 \\
28-65 \\
14 \cdot 0 \\
10 \cdot 8-18 \cdot 2 \\
136 \\
110-178\end{array}$ & $\begin{aligned} \mathbf{t}=2.25 \\
\mathrm{p}=<0.05 \\
\mathrm{t}=2.53 \\
\mathrm{p}=<0.05 \\
\mathrm{t}=2.65 \\
\mathrm{p}=<0.05\end{aligned}$ \\
\hline
\end{tabular}

* No significant difference between Groups I and III or Groups II and III.

(2) Plasma volume (PV) in ml. $=\mathrm{BV} \times \frac{100 \text {-haematocrit }}{100}$.

(3) Total mass of intravascular bilirubin in $\mathrm{mg}$. $=\mathrm{PV} \times$ pre-exchange bilirubin concentration in $\mathrm{mg}$. $/ \mathrm{ml}$.

(4) Total mass of bilirubin removed by exchange in $\mathrm{mg}$. = volume of blood removed $x$

$$
\frac{1 \text {-haematocrit of blood removed }}{100}
$$

$\times$ plasma bilirubin concentration of blood removed.

(5) Bilirubin clearance \% $=$

total mass of bilirubin removed (4) total mass of intravascular bilirubin (3) $\times 100$.

Although approximately twice the blood volume was exchanged in each case, variations in haematocrit inevitably led to variations in the size of the plasma volume exchanged, the actual range being 1/6-2:8. Therefore, as it is the plasma and not the red cell fraction which is concerned with bilirubin removal, bilirubin clearance has been expressed per 2 volumes of plasma exchanged.

\section{Results}

Bilirubin removal. In Table II the figures show that the amount of bilirubin removed was increased significantly in Group II and marginally in Group III as compared with the control group. This increase applied whichever method was used to express the amounts of bilirubin removed from the three groups.

Albumin concentration. Table III shows the mean differences in serum albumin concentrations before and after exchange transfusion in the three groups. In the control group there was a mean fall of $0.5 \mathrm{~g} . / 100 \mathrm{ml}$. In Group II the concentration was raised to $5.03 \mathrm{~g} . / 100 \mathrm{ml}$., an increase of $1.42 \mathrm{~g}$./ $100 \mathrm{ml}$. over the pre-exchange level. Group III showed an over-all mean decrease of $0.04 \mathrm{~g} . / 100 \mathrm{ml}$., the post exchange concentration being $3.59 \mathrm{~g} . /$ $100 \mathrm{ml}$.

Effect of albumin priming in Group III (primed) cases. Table IV sets out the effects of administration of albumin on the haematocrit, bilirubin concentration, total bilirubin mass, and albumin concentration, in the time interval between priming with albumin and before starting the exchange. In each case there was a rise in bilirubin and albumin concentrations, the mean increases 
TABLE III

Albumin Concentration Before and After Exchange in the Three Groups

\begin{tabular}{|c|c|c|c|}
\hline Data & Group I & Group II & Group III \\
\hline 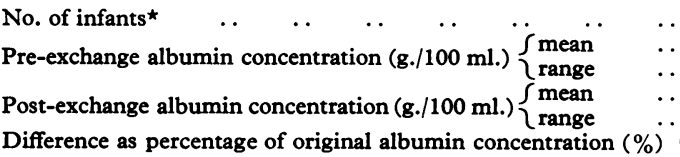 & $\begin{array}{l}8 \\
3 \cdot 76 \\
3 \cdot 2-4 \cdot 1 \\
3 \cdot 29 \\
3 \cdot 0-3 \cdot 6 \\
-12 \cdot 5\end{array}$ & $\begin{array}{l}15 \\
3 \cdot 61 \\
2 \cdot 3-5 \cdot 2 \\
5 \cdot 03 \\
3 \cdot 8-6 \cdot 0 \\
+39 \cdot 3\end{array}$ & $\begin{array}{l}14 \\
3 \cdot 62 \\
3 \cdot 1-4 \cdot 7 \\
3 \cdot 58 \\
2 \cdot 9-4 \cdot 3 \\
-1 \cdot 10\end{array}$ \\
\hline
\end{tabular}

* These figures do not correspond with those in Table $\mathbf{I}$, because albumin concentrations were not measured in all cases.

TABLE IV

Effect of Albumin Priming (Group III)

\begin{tabular}{|c|c|c|c|c|c|c|c|c|c|c|}
\hline \multirow[b]{2}{*}{ Case No. } & \multicolumn{3}{|c|}{ Pre-albumin } & \multirow[b]{2}{*}{$\begin{array}{l}\text { Albumin } \\
(\mathrm{g} . / \\
100 \mathrm{ml} .)\end{array}$} & \multirow{2}{*}{$\begin{array}{l}\text { Albumin } \\
\text { Given } \\
\text { (g.) }\end{array}$} & \multirow[b]{2}{*}{$\begin{array}{c}\text { Time } \\
\text { Interval }\end{array}$} & \multicolumn{4}{|c|}{ Post-albumin (pre-exchange) } \\
\hline & $\begin{array}{c}\text { Haemato- } \\
\text { crit }(\%)\end{array}$ & $\begin{array}{c}\text { Bilirubin } \\
\text { (mg./ } \\
100 \mathrm{ml} .)\end{array}$ & $\begin{array}{l}\text { Bilirubin } \\
\text { Mass } \\
\text { (mg.) }\end{array}$ & & & & $\begin{array}{l}\text { Haemato- } \\
\text { crit (\%) }\end{array}$ & $\begin{array}{c}\text { Bilirubin } \\
\text { (mg./ } \\
100 \mathrm{ml} .)\end{array}$ & $\begin{array}{l}\text { Bilirubin } \\
\text { Mass } \\
\text { (mg.) }\end{array}$ & $\begin{array}{l}\text { Albumin } \\
\text { (g./ } \\
100 \mathrm{ml} .)\end{array}$ \\
\hline $\begin{array}{r}52 \\
55 \\
56 \\
57 \\
60 \\
62 \\
64 \\
70 \\
74 \\
76 \\
77 \\
79 \\
92 \\
94 \\
98 \\
111\end{array}$ & $\begin{array}{l}38 \\
48 \\
46 \\
51 \\
39 \\
41 \\
44 \\
40 \\
41 \\
48 \\
45 \\
39 \cdot 5 \\
36 \cdot 5 \\
40 \\
39 \\
42\end{array}$ & $\begin{array}{l}24 \cdot 6 \\
19 \cdot 0 \\
20 \cdot 3 \\
18 \cdot 8 \\
22 \cdot 0 \\
15 \cdot 1 \\
21 \cdot 4 \\
18 \cdot 4 \\
23 \cdot 2 \\
20 \cdot 4 \\
25 \cdot 8 \\
19 \cdot 7 \\
21 \cdot 2 \\
19 \cdot 4 \\
22 \cdot 1 \\
23 \cdot 8\end{array}$ & $\begin{array}{l}30 \cdot 8 \\
25 \cdot 9 \\
31 \\
16 \cdot 1 \\
34 \\
18 \cdot 7 \\
29 \\
23 \cdot 3 \\
37 \\
24 \cdot 5 \\
32 \cdot 6 \\
36 \cdot 5 \\
32 \cdot 5 \\
30 \cdot 9 \\
30 \\
42 \cdot 3\end{array}$ & $\begin{array}{l}4 \cdot 7 \\
3 \cdot 1 \\
4 \cdot 4 \\
- \\
3 \cdot 5 \\
- \\
- \\
3 \cdot 7 \\
3 \cdot 1 \\
3 \cdot 3 \\
3 \cdot 3 \\
3 \cdot 5 \\
3 \cdot 3 \\
3 \cdot 4 \\
3 \cdot 8 \\
3 \cdot 6\end{array}$ & $\begin{array}{l}3 \cdot 75 \\
10 \cdot 0 \\
7 \cdot 5 \\
3 \cdot 75 \\
7 \cdot 5 \\
5 \cdot 0 \\
5 \cdot 0 \\
3 \cdot 6 \\
10 \cdot 0 \\
5 \\
6 \cdot 25 \\
2 \cdot 5 \\
6 \cdot 25 \\
2 \cdot 5 \\
3 \cdot 75 \\
7 \cdot 5\end{array}$ & $\begin{array}{l}2 \mathrm{hr} . \\
2 \frac{3}{4} \mathrm{hr} . \\
2 \\
2 \frac{h r}{2} \\
2 \frac{1}{2} . \\
2 \mathrm{hr} . \\
2 \mathrm{hr} . \\
2 \frac{1}{3} \mathrm{hr} . \\
2 \frac{1}{2} \mathrm{hr} . \\
6 \mathrm{hr} . \\
2 \frac{1}{4} \mathrm{hr} . \\
3 \mathrm{hr} . \\
2 \mathrm{hr} . \\
2 \frac{1}{4} \mathrm{hr} . \\
2 \frac{3}{4} \mathrm{hr} . \\
2 \mathrm{hr} . \\
2 \frac{1}{2} \mathrm{hr} .\end{array}$ & $\begin{array}{l}30 \\
35 \\
39 \\
45 \\
36 \\
30 \\
33 \\
33 \\
39 \\
38 \cdot 5 \\
42 \\
38 \cdot 5 \\
30 \\
36 \cdot 5 \\
32 \\
39\end{array}$ & $\begin{array}{l}26 \cdot 6 \\
22 \cdot 0 \\
22 \cdot 3 \\
20 \cdot 3 \\
26 \cdot 8 \\
16 \cdot 6 \\
25 \cdot 7 \\
26 \cdot 2 \\
28 \cdot 2 \\
24 \cdot 0 \\
29 \cdot 0 \\
20 \cdot 8 \\
23 \cdot 4 \\
22 \cdot 3 \\
25 \cdot 9 \\
26 \cdot 5\end{array}$ & $\begin{array}{l}37 \cdot 6 \\
37 \cdot 3 \\
39 \cdot 5 \\
19 \cdot 6 \\
43 \cdot 7 \\
24 \cdot 4 \\
41 \cdot 5 \\
37 \\
46 \cdot 5 \\
34 \\
38 \cdot 6 \\
38 \cdot 7 \\
40 \\
37 \cdot 5 \\
39 \cdot 3 \\
56 \cdot 1\end{array}$ & $\begin{array}{l}5 \cdot 3 \\
4 \cdot 3 \\
5 \cdot 4 \\
- \\
4 \cdot 7 \\
- \\
- \\
4 \cdot 5 \\
4 \cdot 4 \\
4 \cdot 1 \\
4 \cdot 2 \\
3 \cdot 6 \\
3 \cdot 8 \\
3 \cdot 7 \\
4 \cdot 8 \\
4 \cdot 1\end{array}$ \\
\hline
\end{tabular}

being $3.2 \mathrm{mg} . / 100 \mathrm{ml}$. and $0.8 \mathrm{~g} . / 100 \mathrm{ml}$., respectively, and a mean fall in venous haematocrit of $6 \%$.

\section{Discussion}

The administration of large amounts $(20$ g.) of human albumin as an adjunct to exchange transfusion resulted in a significant increase in bilirubin removal as compared with simple exchange transfusion. The probable explanation of this effect is that bilirubin diffusion from the extravascular into the intravascular space is accelerated when large numbers of binding sites are made available by the addition of albumin (Sproul and Smith, 1964). In terms of bilirubin removal the results reported here are less impressive than Kitchen's. His cases varied widely as regards age, weight, and especially in pre-exchange serum bilirubin concentration, the mean in the control group being $19.3 \mathrm{mg} . / 100 \mathrm{ml}$. compared with $10.7 \mathrm{mg} . / 100 \mathrm{ml}$. in the albumintreated group. We found that in our cases with pre-exchange bilirubin levels of less than $10 \mathrm{mg}$./ $100 \mathrm{ml}$. (not included in this series) the mean clear- ance was $154 \%$ as compared with $123 \%$ in our control cases with pre-exchange bilirubin levels above 10 $\mathrm{mg} . / 100 \mathrm{ml}$. In addition, these lower levels are of slight clinical interest only, while the method of bilirubin estimation becomes less accurate. Our Group III (primed) cases showed a statistically insignificant increase in bilirubin removal. Expressing our results as $\mathrm{mg}$. bilirubin removed per $\mathrm{kg}$. birthweight, our control group was nearly as effective as Odell's albumin-primed group (see Table V). This difference is difficult to explain unless our control cases were given more plasma relative to the total blood volumes exchanged.

In Group III cases the effect of albumin priming was similar to that in Odell's series, in that there was a marked rise in the serum bilirubin concentration of the order of $3 \mathrm{mg}$. $/ 100 \mathrm{ml}$. As the mean time interval was $2 \frac{1}{2}$ hours, this implies extraction of bilirubin from the tissues and its discharge into the blood. Had no such shift occurred, the bilirubin concentration should have decreased since the plasma volume increased as evidenced by the fall in haematocrit. 
TABLE V

Compariscn of Bilirubin Removal (expressed as mg. bilirubin removed per kg. infant's birthweight)

\begin{tabular}{|c|c|c|c|}
\hline Author & $\begin{array}{c}\text { Simple } \\
\text { Exchange }\end{array}$ & $\begin{array}{l}\text { Albumin } \\
\text { Substituted }\end{array}$ & $\begin{array}{l}\text { Albumin } \\
\text { Primed }\end{array}$ \\
\hline $\begin{array}{l}\text { Odell et al. (1962) }\left\{\begin{array}{l}\text { mean } \\
\text { range }\end{array}\right. \\
\text { Present study }\left\{\begin{array}{l}\text { mean } \\
\text { range }\end{array}\right.\end{array}$ & $\begin{array}{c}9 \cdot 3 \\
5 \cdot 7-13 \cdot 3 \\
11 \cdot 9 \\
5 \cdot 4-20 \cdot 3\end{array}$ & $\begin{array}{c}- \\
15 \cdot 4 \\
9 \cdot 5-24 \cdot 4\end{array}$ & $\begin{array}{c}12 \cdot 33 \\
7 \cdot 7-17 \cdot 2 \\
14 \cdot 0 \\
10 \cdot 8-18 \cdot 2\end{array}$ \\
\hline
\end{tabular}

Bilirubin removal by exchange transfusion is only one aspect of the protection of infants against bilirubin toxicity, as this procedure may only temporarily reduce the level of serum bilirubin. Studies by Diamond and Schmid (1966) suggest that brain damage occurs only when the sites for binding bilirubin to serum albumin are saturated either with bilirubin or competing substances. It follows that by increasing the serum albumin concentration, and therefore the number of available binding sites, the infant should be able to tolerate a level of serum bilirubin which would otherwise lead to brain damage. Having shown in Group II infants that large amounts of albumin administered during the exchange resulted in an increase of serum albumin from a mean of $3.61 \mathrm{~g} . / 100 \mathrm{ml}$. to $5.03 \mathrm{~g} . / 100 \mathrm{ml}$., and that this was well tolerated, the infants in Group III who had a slight fall in total serum albumin at the end of the exchange were then given a booster dose of 2.5 to $3.75 \mathrm{~g}$. albumin to provide further binding sites. The effect of this procedure on the bilirubin-binding capacity of the serum will be discussed in a later publication. Preliminary investigations on these lines, based on the method of Porter and Waters (1966) and Waters (1967), are encouraging, but follow-up periods are still short.

Possible disadvantages in the administration of albumin suggested by Ruys and van Gelderen (1962) were not encountered, care being taken not to use albumin in severely anaemic infants, the lowest haematocrit being 35 . The number requiring subsequent 'top up' transfusion did not exceed expectation.

\section{Conclusion}

Human albumin administered either during, or before and after, exchange transfusion in the amounts quoted is safe in the non-anaemic infant. Within these limits the more albumin given the more bilirubin will be removed. Odell's method of priming before an exchange may provide some immediate protection for the brain while awaiting collection and cross-matching of suitable donor blood. A further boost afterwards should provide further cover during the rebound phase by providing additional binding sites.

\section{Summary}

A total of 53 infants undergoing exchange transfusion for hyperbilirubinaemia were divided into two albumin-treated groups, and a control group. One group received a total of about $20 \mathrm{~g}$. human albumin intravenously during the course of exchange; a significant increase in bilirubin removal resulted. The other group received a 'priming' dose of about $1.75 \mathrm{~g} . / \mathrm{kg}$. albumin intravenously 1-6 hours before exchange; no significant increase in bilirubin removal resulted.

We are indebted to the Birmingham Children's Hospital Research Fund for a grant to complete this work. We are very grateful to Miss J. Cooke, B.Sc., and Mr. L. B. Roberts, A.R.I.C., for carrying out the biochemical investigations. The statistical analysis was carried out by Miss D. J. Powell, B.Sc., and Dr. J. A. H. Waterhouse, M.A., Ph.D.

\section{REFERENCES}

Bartholomew, R. J., and Delaney, A. M. (1966). Sulphonphthaleins as specific reagents for determination of albumin in serum. Proc. Aust. Ass. clin. Biochem., 1, 214.

Diamond, I., and Schmid, R. (1966). Experimental bilirubin encephalopathy. The mode of entry of bilirubin $-{ }^{14} \mathrm{C}$ into the central nervous system. f. clin. Invest., 45, 678.

Forfar, J. O., Keay, A. J., Elliott, W. D., and Cumming, R. A. (1958). Exchange transfusion in neonatal hyperbilirubinaemia. Lancet, 2, 1131 .

Gairdner, D., Marks, J., Roscoe, J. D., and Brettell, R. O. (1958). The fluid shift from the vascular compartment immediately after birth. Arch. Dis. Childh., 33, 489.

Kitchen, W. H., Krieger, V. I., and Smith, M. A. (1960). Human albumin in exchange transfusion. F. Pediat., 57, 876.

Mollison, P. L., Veall, N., and Cutbush, M. (1950). Red cell and plasma volume in newborn infants. Arch. Dis. Childh., 25, 242.

Odell, G. B. (1959a). Studies in kernicterus. I. The protein binding of bilirubin. f. clin. Invest., 38, 823 .

- (1959b). The dissociation of bilirubin from albumin and its clinical implications. F. Pediat., 55, 268.

- Cohen, S. N., and Gordes, E. H. (1962). Administration of albumin in the management of hyperbilirubinemia by exchange transfusion. Pediatrics, 30, 613.

Porter, E. G., and Waters, W. J. (1966). A rapid micromethod for measuring the reserve albumin binding capacity in serum from newborn infants with hyperbilirubinaemia. f. Lab. clin. Med., $67,660$.

Ruys, J. H., and van Gelderen, H. H. (1962). Administration of albumin in exchange transfusion. F. Pediat., 61, 413.

Sproul, A., and Smith, L. (1964). Bilirubin equilibration during exchange transfusion in hemolytic disease of the newborn. ibid., 65, 12.

Valaes, T. (1959). Neonatal hyperbilirubinaemia. Lancet, 1, 208. - (1963). Bilirubin distribution and dynamics of bilirubin removal by exchange transfusion. Acta paediat. (Uppsala), 52, Suppl. 149.

Waters, W. J. (1967). The reserve albumin binding capacity as a criterion for exchange transfusion. F. Pediat., 70, 185.

-, and Porter, E. (1964). Indications for exchange transfusion based upon the role of albumin in the treatment of hemolytic disease of the newborn. Pediatrics, 33, 749.

White, D., Haidar, G. A., and Reinhold, J. G. (1958). Spectrophotometric measurement of bilirubin concentrations in the serum of the newborn by the use of a microcapillary method. Clin. Chem., 4, 211. 